\title{
Zastosowanie metody Taguchiego do poprawy efektywności androgenezy w zbożowych kulturach in vitro
}

\author{
Application of the Taguchi method in the androgenesis efficiency enhancment \\ in cereal tissue cultures
}
RenataOrłowska $^{1 凶}$, Katarzyna Anna Pachota ${ }^{1}$, Joanna Machczyńska ${ }^{1}$, Agnieszka Niedziela ${ }^{1}$, Janusz Zimny ${ }^{2}$, Piotr Tomasz Bednarek ${ }^{1}$

\author{
${ }^{1}$ Instytut Hodowli i Aklimatyzacji Roślin — Państwowy Instytut Badawczy, Zakład Biochemii i Fizjologii Roślin, \\ Radzików, 05-870 Błonie \\ ${ }^{2}$ Zakład Biotechnologii i Cytogenetyki Roślin \\ e-mail: r.orlowska@ihar.edu.pl
}

\begin{abstract}
W zbożowych kulturach in vitro jednym $\mathrm{z}$ najtrudniejszych problemów do przezwyciężenia $\mathrm{w}$ trakcie produkcji podwojonych haploidów (DH) jest albinizm. Wydaje się, że dość skutecznym sposobem redukowania albinizmu jest dobór odpowiedniego czynnika stresowego w połączeniu ze zbalansowanym składem pożywek. W prezentowanej pracy zastosowano suplementację pożywek jonami miedzi i srebra $\left(\mathrm{CuSO}_{4}, \mathrm{AgNO}_{3}\right)$ oraz modulowano czas kultur na pożywkach indukujących dla trzech gatunków zbóż: jęczmienia (Hordeum vulgare L.), pszenicy (Triticum aestivum L.) oraz pszenżyta (x Triticosecale spp. Wittmack ex A. Camus 1927). Zastosowanie metody Taguchiego pozwoliło na ograniczenie liczby eksperymentów oraz umożliwiło zoptymalizowanie warunków prowadzenia kultur in vitro, co ostatecznie wpłynęło na poprawę ilości zielonych regenerantów u wszystkich zastosowanych gatunków.
\end{abstract}

Słowa kluczowe: Metoda Taguchiego, optymalizacja, zbożowe kultury in vitro, androgeneza, $\mathrm{CuSO}_{4}, \mathrm{AgNO}_{3}$, czas indukcji

In cereal tissue cultures, one of the most difficult problems to overcome during the production of doubled haploids $(\mathrm{DH})$ is the albinism. It seems that a quite effective way to reduce albinism is to choose the right stress factor in combination with a balanced composition of medium. In the presented work supplementation of nutrients with copper and silver ions $\left(\mathrm{CuSO}_{4}, \mathrm{AgNO}_{3}\right)$ and modulation of cultures time on induction medium for three cereal species: barley (Hordeum vulgare L.), wheat (Triticum aestivum L.) and triticale (x Triticosecale spp. Wittmack ex A. Camus 1927) were used. Application of the Taguchi method enabled to limit the number of experiments and to optimize the conditions for tissue cultures, which enhanced of the amount of green regenerants in all analyzed species.

Key words: Taguchi method, optimization, cereal tissue cultures, androgenesis, $\mathrm{CuSO}_{4}, \mathrm{AgNO}_{3}$, induction length

Techniki pozyskiwania podwojonych haploidów (DH) od momentu ich wynalezienie do dziś pozwalają na pozyskiwanie cennych materiałów, które w znaczący sposób przyspieszają wprowadzanie nowych odmian hodowlanych na rynek. Jednakże masowa produkcja DH nie jest procesem łatwym i natrafia na pewne trudności, takie jak przygotowanie odpowiedniego materiału wyjściowego czy też przełamanie naturalnych barier roślin do podwajania garnituru chromosomowego w warunkach in vitro. W zbożowych kulturach in vitro jednym z najtrudniejszych problemów do przezwyciężenia $\mathrm{w}$ trakcie produkcji roślin DH jest albinizm. Wynika to z faktu pozyskiwania roślin DH na drodze androgenezy w kulturach pylnikowych lub izolowanych mikrospor. Dotychczas, w celu poprawy wydajności procesu androgenezy, koncentrowano się na doborze odpowiedniego materiału wyjściowego do kultur, wytypowaniu odpowiedniej fazy rozwojowej mikrospor, na modyfikacji czynników stresowych indukujących androgenezę lub na optymalizacji składu pożywek do hodowli. Wydaje się, że dość skutecznym sposobem redukowania albinizmu jest dobór odpowiedniego czynnika stresowego w połączeniu ze zbalansowanym składem pożywek. W prezentowanej pracy zastosowano suplementację pożywek jonami miedzi i srebra $\left(\mathrm{CuSO}_{4}, \mathrm{AgNO}_{3}\right)$ oraz modulowano czas kultur na pożywkach indukujących dla trzech gatunków zbóż: jęczmienia (Hordeum vulgare L.), pszenicy (Triticum aestivum L.) oraz pszenżyta (x Triticosecale spp. Wittmack ex A. Camus 1927). Dobór czynników został podyktowany ich pozytywnym wpływem na proces androgenezy. Jony miedzi obecne w pożywkach hodowlanych mogą stymulować regenerację oraz powstawanie zielonych regenerantów. Także jony srebra pozytywnie wpływają na produkcję i wzrost embrionicznego kalusa podczas otrzymywania regenerantów. Zastosowanie metody Taguchiego 
pozwoliło na ograniczenie liczby eksperymentów oraz umożliwiło zoptymalizowanie warunków prowadzenia kultur in vitro. $\mathrm{W}$ pośrednim etapie doświadczenia obserwowano wzrost liczby zielonych regenerantów oraz redukcję roślin albinotycznych u wszystkich testowanych gatunków.
Ostatecznie zastosowanie metody Taguchiego pozwoliło na poprawę ilości zielonych regenerantów u wszystkich zastosowanych gatunków, jednakże u pszenżyta cały proces optymalizacyjny został potwierdzony statystycznie.

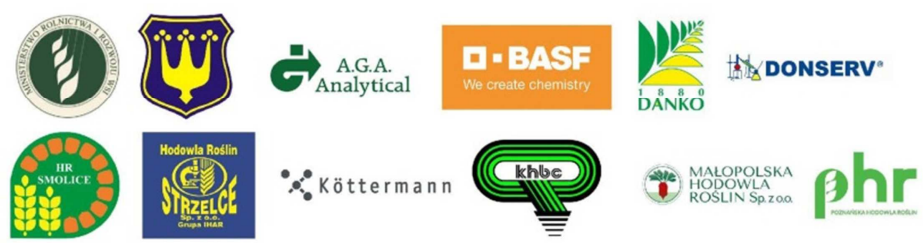

